\title{
Screening of rice varieties against leaf folder Cnaphalocrocis medinalis Guenee (Lepidoptera : Pyralidae)
}

\section{A. M. Kakde* and K.G. Patel ${ }^{1}$}

Department of Entomology, N. M.College of Agriculture, Navsari Agricultural University, Navsari (Gujarat) India ${ }^{1}$ College of Agriculture, Bharuch (Gujarat) India

\section{ARITCLE INFO}

Received : 31.05 .2018

Revised : 01.09 .2018

Accepted : 16.09.2018

\section{KEY WORDS :}

Leaf folder, Resistant, Susceptible

*Corresponding author: amoljau@gmail.com

\section{ABSTRACT}

The findings on per cent leaf damage due to leaf folder showed that varieties like GR102, GR-103 considered as resistant (R). However, the variety GR-101 found susceptible (S) and varieties considered as highly susceptible (HS) were GR-12, Jaya, GR-104 and Masuri.

How to view point the article : Kakde, A.M. and Patel, K.G. (2018). Screening of rice varieties against leaf folder Cnaphalocrocis medinalis Guenee (Lepidoptera: Pyralidae). Internat. J. Plant Protec., 11(2) : 135-140, DOI : 10.15740/HAS/IJPP/11.2/135-140, Copyright@ 2018: Hind Agri-Horticultural Society. 